\title{
Development of Teaching Material for Narrative Writing using Graphic Organizer Story Map in Elementary School
}

\author{
Ramona Kurnia ${ }^{1^{*}}$, Darnies Arief ${ }^{2}$ Irdamurni $^{3}$ \\ 1,2,3 Universitas Negeri Padang, Padang Indonesia. \\ *Corresponding author, e-mail: ramonakurnia2209@gmail.com
}

\begin{abstract}
Most of materials used in narrative writing are not interested and not related to the writing process (pre-writing, when writing, and post writing). Our goal is to measure the effectiveness, practicality, and validity of the narrative writing material namely Graphic Organizer Story Map. We are doing research and development. We used 4-D model which consists of 4 stages: define, design, develop and disseminate. The validity test is obtained through the learning plan sheet on implementation, and the assessment of teachers and students responses. The effectiveness is obtained from activity, process assessment and result of narrative writing. We conducted an evaluation and obtained the "very valid", "very simple" and "very effective". We found the enhancement number of student who meet the passing grade on narrative writing. The teaching material for narrative writing with using Graphical Organizer Story Map is valid, simple and effective to use.
\end{abstract}

Keywords: Graphic Organizer, Story Map, Narrative.

How to Cite: Kurnia, R., Arief, D., \& Irdamurni, I. (2017). Development of Teaching Material for Narrative Writing using Graphic Organizer Story Map in Elementary School. International Journal of Research in Counseling and Education, 1(1), 22-26. https://doi.org/10.24036/009za0002 original work is properly cited. (C2017 by author and Universitas Negeri Padang.

\section{Introduction}

Basic skills such as listening, speaking, reading, and writing skills must be possessed by students (Tarigan, 2008:1). Among that four language skills, writing skills are the most difficult to be mastered. This is because writing skills require mastery of various linguistic elements. As Saddhono (2012) points out that "writing is a very complex activity because it involves a regular way of thinking and various requirements related to writing techniques. Therefore, writing skills are mastered by someone after mastering other language skills ".

Writing skill learning have many obstacles for elementary school implementation. Kumara (2016) points out some of the teaching constraints: 1) The basic weakness of teacher is to override language as a living and developing things, so there is no creativity and contextualization of the material in Indonesian language teaching techniques. 2) Teachers explain the theory of writing narratives, expositions, and arguments, but rarely give their students time to practice in writing. 3) Students interest in reading has an impact to the student's vocabulary and pouring ideas.

Writing skill mastering can be achieved through the interaction of various factors, such as using the teaching materials. Daryanto and Dwicahyono (2014) argued that teaching materials are a set of materials that arranged systematically both written and unwritten to create an environment or atmosphere that allows student to learn. Based on some research on teaching materials which implemented in Turkey (Halil Ibrahim, 2011), Taiwan (Kuo-En Chang, Yao-Ting Sung and Huei-Tse Hou, 2015), Singapore 
(Andrew Littlejohn, 2012), and Indonesia (Rahmita Yuliana Gazali, 2016) generally pointing on how the teaching materials to improve the learning outcomes, especially in writing. Teaching materials are intended the writing process to be more effective, efficient, fast, and meaningful for students.

We conduct an observation and found some problems in learning narrative writing in SD Negeri Ulakan Tapakis. First. The teaching materials used by teachers less able to attract learners and less illustrate success in learning writing. Secondly, less teaching materials provide a stimulus for pre-writing so students have trouble getting started writing. Third, the theme / topic of the story on monotonous and less contextual material. Fourth, teaching materials do not contain the process of writing a complete narrative, namely: pre-writing, while writing, and post-writing. Fifth, teaching materials do not contain writing strategies to facilitate students to organize an idea so their essay tends not to have a clear path.

The issues above need to be addressed immediately. To overcome these problems, we propose a teaching materials and design an appropriate learning strategies to foster the student interest in writing. Teaching materials and learning strategies are designed base on characteristics and need of students. Graphic Organizer is one of suitable strategy to develop the narrative writing material. According to Zaini (2010), Graphic Organizer is a chart to group the important concepts in a text, organize the information to be structured and connected a concept with another concept into a whole article.

According to McKnight, Graphic Organizer consists of 105 types. One of the graphic organizers that is suitable to use in teaching narrative writing materials is graphic organizer story map. According to Jonson (in McKnight, 2006), Story Map is a Graphic Organizer that displays elements in writing a story or essay. The middle circle serves the title or topic that will be created by students. The second circle serves the outline or other things as a part of story. The third circle serves as a story development. Graphic Organizer Story Map is used as a visual medium that shows the relationship between ideas and facts that occur in the story. Through the Graphic Organizer Story Map, students learn the relationship between parts or elements of the story.

The goals of this study are (1) produce teaching materials using valid Graphic Organizer Story Map model for grade $5^{\text {th }}$ Elementary School. (2) Produce a simple learning material using the model of Graphic Organizer Story Map for grade $5^{\text {th }}$ Elementary School. (3) Produce learning materials using an effective Graphic Organizer Story Map model for Grade $5^{\text {th }}$ elementary school student.

\section{Method}

This is a development research. Sujadi (2003) reveals that development research is a process or step to develop a new product or refine the previous product. We use 4-D (four D models) in the development process. According Sugiyono (2009) 4-D model stages consist of definition, design, development, and disseminate.

On define stage, curriculum analysis, requirement analysis, and learner analysis are performed. The result of this analysis will be used as a foundation to design a teaching materials. The design of teaching materials includes all components of teaching materials according to DEPDIKNAS consist of: (1) cover, (2) introduction, (3) table of contents, (4) user guide, (5) SK and KD to be achieved, (6), (7) goals to be achieved, (8) tasks or activities, (9) supporting information, and (10) bibliography.

After designing the teaching materials, we developed the learning materials in SDN 02 Ulakan Tapakis. The $5^{\text {th }}$ grade consists of 18 students. The development stage includes the validity of teaching materials, the practice of teaching materials, and the effectiveness of teaching materials. Stage of validity is done to the aspect of content, language, and the graffiti of teaching materials. Instrument used are the validation of material content validation sheet, language validation material sheet, and validation sheet of teaching material's graffiti. All instruments are first validated by the instrument expert. Practicality stage aims to see the of convenience and practicality level of the teaching materials. The instruments used are the observation sheets of RPP implementation, teacher response questionnaire, and student response questionnaire. Effectiveness stage is performed to find out the maximum goal is expected to be achieved through the materials developed. The instruments used are observation sheets of student activity on effectiveness, assessment sheet of narrative writing process, and score sheet of narrative writing skill.

Disseminate stage is performed to see the effectiveness of the teaching materials we developed on a wider scale. The distribution is conducted in SDN 07 Ulak Karang Selatan, Padang City with 22 students. 
We prove that narrative writing materials using Graphic Organizer Story Map not only effectively used in rural areas, but also in urban areas. The limitation of the dissemination is only performed to one school

\section{Results and Discussion}

The results of research on developing the teaching materials to write narrative using graphic organizer story map can be seen from the level of validity, practicality, and effectiveness.

\section{Validity}

The purpose of teaching materials validation is to determine the product functionality based on the content, language, presentation and graffiti. The main parts that are validated the suitability of $\mathrm{KD}$, the indicator, the truth of the concept, and the language used. The learning material that ready to test is the learning material that validated by validators.

Validation activities involve some experts and educational practitioners in accordance with the field of study which consist of six validators expert, three validators for content and linguistic experts, three validators for graffiti expert, and 3 validator form practisioner (elementary school teachers). The results showed that teaching materials to write narrative using Graphic Organizer Story Map obtained $88.07 \%$ with very valid criteria from expert validator. Meanwhile, from practitioner validator get percentage $88,67 \%$ with criterion very valid. The validity of teaching materials on narrative writing using Graphic Organizer Story Map for $5^{\text {th }}$ Grade in Elementary School that we developed in this research is valid in terms of content and constructs. This is in appropriate with validation results from expert validator and validator of education practitioner. The results illustrate that the teaching material has been validated and can be used in the learning process.

\section{Practicality}

After the validation process with the experts completed, we conduct a test to see the practicality of the teaching materials. Tests conducted on three meeting. During the trial, the study was monitored by two observers. Based on the test, we found that teaching materials on narrative writing with Graphic Organizer Story Map meet the practical criteria. The practicality of teaching materials on narrative writing using Graphic Organizer Story Map for $5^{\text {th }}$ grade in Elementary School as a whole in very practical category. Based on the observation of the implementation of RPP earn $89.40 \%$ for very practical category. The result of questionnaire of teacher response obtained $93 \%$ percentage for very practical category, and student response assessment $88,60 \%$ for very practical category. This result provides an illustration that the teaching materials on narrative writing using Graphic Organizer Story Map for $5^{\text {th }}$ grade in Elementary School is very practical and can assist in implementing the narrative writing learning process.

\section{Effectiveness of teaching materials}

The effectiveness of teaching materials can be observed through the assessment of student activities, assessment of narrative writing process, and the result of narrative writing skills. The assessment results of student activity obtained $91.10 \%$ with very good categories. Then the assessment of the narrative writing process obtained $84.25 \%$ with very high category, and the assessment of narrative writing skill obtained $86.9 \%$. The observation of students' activity, process assessment, and assessment result of narrative writing of students give a very good picture. It means the use of teaching materials in narrative writing has been effectively implemented. The results of research for more details can be seen in the following tables and diagrams.

Table 1.1 Recapitulation of Teaching Materials Assesment

\begin{tabular}{|l|l|l|c|c|}
\hline No. & Aspect & Result & Category \\
\hline \multirow{2}{*}{1.} & Validity & Content & $91,3 \%$ & Very valid \\
\cline { 3 - 5 } & & Language & $84,1 \%$ & Very valid \\
\cline { 3 - 5 } & & Graffiti & $86,4 \%$ & Very valid \\
\hline \multirow{2}{*}{2.} & \multirow{2}{*}{ Practicality } & RPP implementation & $89,40 \%$ & Very simple \\
\cline { 3 - 5 } & & Teachers response & $93 \%$ & Very simple \\
\cline { 3 - 5 } & & Students response & $88,60 \%$ & Very simple \\
\hline \multirow{2}{*}{3.} & \multirow{2}{*}{ Effectiveness } & Student activities & $91,10 \%$ & Very high \\
\cline { 3 - 5 } & & Students writing process & $84,25 \%$ & Very high \\
\hline
\end{tabular}




\begin{tabular}{|l|l|l|c|c|}
\hline & & Student writing result & $86,9 \%$ & Very high \\
\hline
\end{tabular}

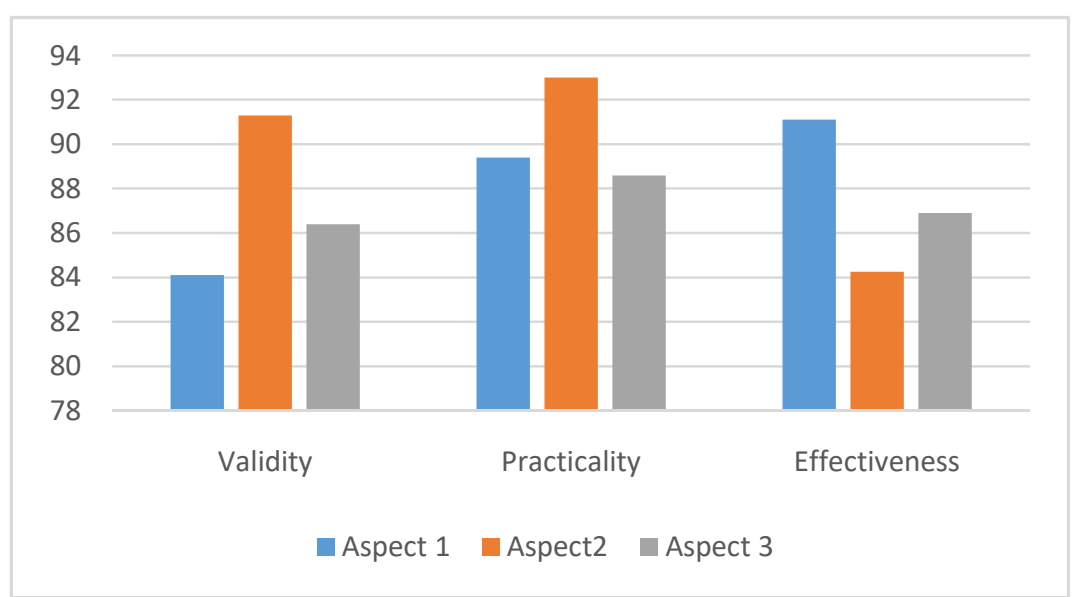

Picture 1.1

Recapitulation of Teaching Materials Assesment

Aspect 2 Language

Aspect 3 Graffiti

\section{Description}

Practicality

RPP Implementation

Teachers response

Students response

\section{Effectivity}

Students activities

Students writing process

Students writing results

\section{Conclusion}

Based on the development and experiments we conducted for narrative writing using Graphic Organizer Story Map for $5^{\text {th }}$ grade in Elementary School, got the following conclusion.

1. The validity of teaching materials to write narrative using Graphic Organizer Story Map in class V Elementary School

The results showed that teaching materials to write narrative using Graphic Organizer Story Map meet the validity criteria. This is supported by the validation results from expert validators and educational practitioner validators. These results illustrate that the developed teaching material has been valid and can be used in the learning process.

2. Practicality teaching materials to write narrative using Graphic Organizer Story Map for $5^{\text {th }}$ grade in Elementary School

The results showed that teaching materials to write narrative using Graphic Organizer Story Map has very practical criteria. This result is obtained from the observation of the RPP implementation toward teacher, teachers response, students response, and the observation sheet of teaching materials. This result gives an illustration that the teaching material is very simple and assist in carrying out the process of learning narrative writing for $5^{\text {th }}$ grade in Elementary School.

3. The Effectiveness of teaching Materials for Narrative Writing using Graphic Organizer Story Map for $5^{\text {th }}$ grade Elementary School

The result illustrated that narrative writing teaching material using Graphic Organizer Story Map meet the effectivity criteria. The observation result of students' activity, process assessment, and assessment of narrative writing result give a very good picture. It means the use of teaching materials for learning narrative writing has been effectively implemented.

\section{References}


Andrew Littlejohn. (2012). Language Teaching Materials and the (Very) Big Picture. Electronic Journal of Foreign Language Teaching. Vol. 9, Suppl. 1.

Daryanto \& Dwicahyono. (2014). Pengembangan Perangkat Pembelajaran (Silabus, RPP, PBH, Bahan Ajar). Yogyakarta: Gva Media

Halil Ibrahim. (2011). An Investigation On Teaching Materials Used In Social Studies Lesson. The Turkish Online Journal of Educational Technology. Vol. 10, Issue 1

Tarigan, Henry Guntur. 2008. Membaca Sebagai Suatu Keterampilan Berbahasa. Bandung: Angkasa.

Kumara, A. (2016). Kemampuan Verbal Terhadap Ekspresi Tulis. Journal Psikologi. 2(1)

Kuo-En Chang, Yao-Ting Sung dan Huei-Tse Hou. (2015). Web-based Tools for Designing and Developing Teaching Materials for Integration of Information Technology into Instruction. Educational Technology \& Society. Vol. 9, No. 4, ISSN 1436-4522 (online) and 1176-3647 (print).

McKnight, K. S. (2013). The Elementary Teacher's Big Book of Graphic Organizers. San Fransisco: Josscy-Bass

Rahmita Yulia Gazali. (2016). Pengembangan bahan ajar matematika untuk siswa SMP berdasarkan teori belajar ausubel. PYTHAGORAS: Jurnal Pendidikan Matematika, 11(2), 182-192. p-ISSN: 1978-4538 | e-ISSN: 2527-421X. doi:http://dx.doi.org/10.21831/pg.v11i2.10644.

Saddhono, K \& St.Y.Slamet. (2012). Meningkatkan Keterampilan Berbahasa Indonesia (Teori dan Aplikasi). Bandung: Karya Putra Darwati.

Sugiyono. (2012). Metode Penelitian Pendidikan Kuantitatif, Kualitatif, dan R\&D. Bandung: Alfabeta

Sujadi. (2003). Metode Penelitian Pendidikan. Jakarta: Rineka Cipta

Zaini, Syaza Hazwani. (2010). The Effect of Graphic Organizer on Students' Learning in School. Malaysian Journal of Educational Technology. 10(1), 17-23. 